\title{
Loneliness and its associated Factors in Community-living Elderly People who Use Day Care Services
}

\author{
Akira NARUSAWA $^{1}$, Yumiko SAKATA ${ }^{2}$ and Yuriko TAKATA ${ }^{2}$
}

This study aimed to clarify the degree of loneliness and its associated factors in elderly people who use day care services. Interviews were conducted using an interview schedule. A $\chi^{2}$ test was performed to verify the independence of various factors associated with loneliness. Significant items were then used as independent variables in multiple logistic regression analysis with the presence or absence of loneliness as the dependent variables.

This study included 200 community-dwelling elderly people who used day care services [53 men (26.5\%) and 147 women (73.5\%)]. The respondents had a mean \pm standard deviation score of 38.44 \pm 9.43 on the loneliness scale. The results of the $\chi^{2}$ test indicated that a significant number of elderly people in the "lonely group" were not socially active $(p=0.010)$, lived in apartment complexes $(p=0.036)$, or did not have hobbies $(p=0.037)$. Multiple logistic regression analyses revealed that loneliness was significantly associated with social participation [odds ratio (OR): 0.148 ; $95 \%$ confidence interval (CI): $0.03-0.66 ; p=0.012$ ] and type of residence (OR: $0.464 ; 95 \%$ CI: $0.23-0.94$; $p=0.033)$.

The results demonstrated that loneliness in the elderly is clearly associated with their social participation and living situations as well as their hobbies and activities. These findings have important implications for understanding loneliness in community-living elderly people who use day care services.

Key words : day care service, community-living elderly, loneliness, social network, social support

\section{Introduction}

The aging population of Japan is rapidly increasing because of the decrease in mortality rate, increase in average lifespan, and decrease in fertility, which in turn has led to a decrease in the number of young individuals ${ }^{1}$. Social isolation, loss of interest in living, risk of consumer fraud or crime, and dying alone are recognized social problems in elderly people ${ }^{2,3}$. Thus, social isolation among elderly people has become an important policy issue, and local government administrations have attempted various measures to address $i^{4,5)}$.

Townsend ${ }^{6)}$ described loneliness as a subjective concept and social isolation as an objective concept, thereby differentiating the two. In terms of the structure of loneliness across a lifespan, $\mathrm{Ochiai}^{7)}$ revealed that loneliness in people becomes more complex with advancing age. Moreover, Momtaz ${ }^{8}$ demonstrated that an increase in loneliness negatively affects one's ability to deal with the causes of stress and that lonely middle-aged and elderly peo-

\footnotetext{
${ }^{1}$ University of Tsukuba Graduate School of Comprehensive Human Sciences Majors of Medical Sciences

${ }^{2}$ University of Tsukuba
} 
ple tend to refuse emotional support intervention. The nature of loneliness in the elderly is complex, and they are more likely to not express their feelings of loneliness. Therefore, it is difficult for specialists to identify high levels of loneliness in elderly individuals. In recent years, it has been reported that loneliness can have an impact on hypertension, mortality, and depressive tendencies ${ }^{8-11)}$. Therefore, healthcare professionals need to be able to identify and provide support to elderly people who experience loneliness even when they cannot express these feelings.

Studies on loneliness have primarily focused on understanding the state of loneliness and its associated factors among community-dwelling elderly people. Moreover, studies in Japan have examined elderly people who live alone ${ }^{12)}$, live overseas ${ }^{13)}$, and experience bereavement ${ }^{14)}$, whereas studies outside Japan have paid particular attention to the manner in which loneliness affects sick or disabled elderly people ${ }^{15,16)}$. However, we were unable to identify any study regarding loneliness among elderly people who use day care services. The purpose of day care is to alleviate loneliness, maintain physical and mental functions, and decrease the burden on families who care for elderly people ${ }^{17)}$. For this reason, loneliness among community-dwelling elderly people who use day care services is likely to be high. It is important to identify the prevalence of loneliness in this population.

Numerous studies in Japan have investigated social networks ${ }^{18,19)}$ and subjective sense of health ${ }^{20)}$, whereas studies from overseas have examined marital status ${ }^{15,21)}$, illness, and disabilities as factors associated with loneliness ${ }^{15,16,21)}$. While the literature in both Japan and abroad identifies similar factors associated with loneliness in the elderly, some results differ. More empirical studies are required to increase our understanding of the phenomenon of loneliness in the elderly; furthermore, it is also important to integrate the results of these studies.

Therefore, the aim of this study was to identify the prevalence of loneliness among community-dwelling elderly people who use day care services and the primary factors associated with loneliness. This study will serve as a basic resource in determining the manner in which support should be provided to elderly people in order to alleviate their loneliness.

\section{Methods}

\section{Definitions}

This study refers to the definition of loneliness as "an unpleasant and subjective experience that arises when the level of a person's actual social relationships is smaller or less satisfying than the person desires," as stated by Peplau and Perl$\operatorname{man}^{22)}$. The UCLA Loneliness Scale is based on this definition and measures differences in each individual's experience of loneliness. The more an individual ages, the more complex the nature of his/ her loneliness becomes ${ }^{23)}$. Therefore, the nature of loneliness needs to be captured in multiple dimensions. In this study, elderly individuals with weak social networks and social support as well as a greater subjective sense of loneliness were considered to be lonely.

\section{Study subjects}

The study subjects were community-dwelling elderly people who used day care services and who were aged $\geq 65$ years, were able to answer our questions, and who agreed to participate after the aims of the study had been described. We used the revised Hasegawa Dementia Scale (HDS-R) ${ }^{24)}$ to evaluate each subject's cognitive capacity to understand and respond to the questions. Respondents who scored $\leq 20$ were excluded.

\section{Sampling method}

We performed a search in the Welfare and Medical Service Network ${ }^{25)}$ (WAMNET) database for 
"day care services" (excluding day rehabilitation services) registered in Tokyo's A Ward. We then contacted the resultant 48 centers via telephone to recruit participants for our study. The supervisors of nine of these centers agreed to participate in the study. We sent an explanatory information pack regarding the study to each of them. The details of the study were described both verbally and through documents. After obtaining approval from the head of the organization or from another responsible individual, we were introduced to potential subjects who used day care services.

Furthermore, we used convenience sampling to collect data from eight facilities across the following six communities: Ward B (two facilities), Ward C (two facilities), Ward D, and Ward E in Tokyo; City F in Kanagawa Prefecture; and City G in Nagano Prefecture. We explained the details of the survey both orally and in writing to each facility director who referred the survey subjects. Wards A-E in Tokyo were considered as "urban areas," and Cities $\mathrm{F}$ and $\mathrm{G}$ were considered as "rural areas."

\section{Details of the study}

\section{1) Study method}

The study was conducted between April 1, 2013 and March 31, 2015. Interviews were conducted using an interview schedule.

\section{2) Survey item}

\section{(1) Establishing loneliness}

The subjects' subjective feelings of loneliness were computed by measuring their degree of loneliness, social networks, and social support.

\section{i. Loneliness}

Loneliness was measured using the Japanese version of the UCLA Loneliness Scale (Version 3) (20 items with answers on a scale of $1-4)^{26,27)}$. The potential score range was $20-80$ with higher scores indicating greater degrees of loneliness. People who scored $\geq 44$ were classified as "severely lonely," those who scored 28-34 were "moderately lonely," and those who scored $<28$ were "not particularly lonely."

Masuda et al. ${ }^{27)}$ previously verified the reliability ( $\alpha$ coefficient: 0.92 ) and validity of the scale.

\section{ii. Social networks}

The status of social networks was measured using the Japanese version of the abbreviated Lubben Social Network Scale (LSNS-6 ${ }^{28,29)}$, which evaluates social isolation in elderly people and has been widely used internationally. It is comprised of three items related to kin networks and three items related to non-kin networks (friendships), totaling six items. Respondents were asked to specify the number of individuals in each of the six categories [0 (none) to 5 (nine or more)]. The range of the potential score was $0-30$ with higher scores indicating more social engagement.

Kurimoto et al.$^{29)}$ previously verified the reliability ( $\alpha$ coefficient: 0.82 , test-retest reliability: 0.92 ) and validity of the scale.

\section{iii. Social support}

Social support was measured using the Japanese version of the Multidimensional Scale of Perceived Social Support (MSPSS) ${ }^{30,31)}$, which is a social support scale that was developed for general use and has become a standard for community-dwelling elderly people. There were four items each for "family support," "significant other support," and "support from friends," totaling 12 items with seven possible responses. The range of the potential score was $12-84$ with a higher score indicating a higher degree of social support.

Iwasa et $a l .{ }^{31)}$ previously verified the reliability ( $\alpha$ coefficients of Total Score: 0.91; Family subscale: 0.94; Significant Other subscale: 0.88 ; Friends subscale: 0.90 ) and validity of the scale.

In this study, the respondents who scored at the lower end of both the LSNS-6 $(<12)$ and MSPSS $(12-48)$ and who were in the "severely lonely group" on the UCLA Loneliness Scale $(\geq 44)$ were 
classified as the "lonely group"; the remaining respondents were placed in the "not lonely group."

\section{(2) Factors associated with loneliness}

The following items that have been previously investigated in association with loneliness were used to investigate the factors associated with loneliness for this study: basic attributes, physical factors, psychological factors, social factors, and environmental factors.

The basic attributes included sex, age, use of day care services (duration and frequency of use), family situation, marital status [past marriage(s) and/ or current spouse], having children, having experienced bereavement, duration of bereavement, and having hobbies. The physical factors included any illnesses and activities of daily living (ADL) and instrumental ADL (IADL) to estimate the level of care required. The psychological factors included subjective perceptions of health (number of subjective symptoms), history of depression, and history of irritability. The social factors included outings (i.e., outings to destinations other than day care service, social participation, or lack of social activity), use of care services (home-visit service and day rehabilitation services), and use of a mobile telephone or the internet. The environmental factors included the location of residence, type of residence, and duration of stay in the current residence.

\section{3) Data collection method}

Using an interview schedule, interviews were conducted using the following concepts:

(1) Number of interviews: One interview was conducted per respondent. However, if all answers were not obtained during the first interview due to health problems or scheduling conflicts, a second interview was conducted.

(2) Interview duration: Each interview took approximately $30 \mathrm{~min}$. However, some interviews took more time because of the respondent's health status or other issues that arose during the response period.

(3) Interview location: Interviews were conducted in various locations ranging from individual rooms, at a table some distance from other center users, or in other locations according to the respondent's preference.

\section{Method of analysis}

The $\chi^{2}$ and Fisher's exact tests were conducted for loneliness and each of the following items: basic attributes, physical factors, psychological factors, social factors, and environmental factors. The significance of the association for each item was tested with a significance level of $10 \%$.

Multiple logistic regression analyses (backward elimination, likelihood ratio) were then performed using the items for which significance had been confirmed as independent variables and with loneliness as the dependent variable. The significance level was set at $5 \%$.

\section{Ethical considerations}

This study was conducted with the approval of the Ethics Committee of the Tsukuba University. A responsible person at each day care service provider introduced us to the elderly respondents. The respondents were informed on the aims of the study and that their participation was voluntary and they could withdraw from the study at any time. It was also explained that any disadvantage to respondents would be avoided and that subject anonymity was guaranteed. We informed participants regarding the manner in which the data would be stored, destroyed, and where the results would be published. Having provided this explanation both verbally and through an information sheet, we then obtained the respondents' signatures to indicate that they had agreed to participate. We selected the duration and location of the interviews to reduce the mental and physical burden on the respondents; moreover, we made it clear that interviews 
could be interrupted at any time if the respondent felt unwell.

\section{Results}

The study was conducted at 17 centers in seven local areas. There were 205 respondents; however, five withdrew from the study either during or after the study period, leaving a total of 200 in the final analysis.

\section{1) Basic attributes}

There were 53 (26.5\%) male and 147 (73.5\%) female respondents with a mean age of $83.83 \pm$ 6.58 years. With respect to levels of care required, $55(38.2 \%)$ respondents required support (requiring either support or supervision in everyday activities) and 89 (61.8\%) required care (requiring care in everyday activities). The cognitive function on HDS-R was verified in 130 respondents with a mean \pm standard deviation score of $25.83 \pm 2.67$ (Table 1).

For elderly subjects who refused confirmation of cognitive function, we used the "Basic checklist" created by the Ministry of Health, Labor, and Welfare for the selection of subjects who were not certified as needing care but who were at risk of needing support or care, and we verified that the items on dementia did not apply to them.

\section{2) Loneliness}

(1) Classification of Loneliness Using the

\section{UCLA Loneliness Scale (Version 3)}

Using the revised UCLA Loneliness Scale, the mean loneliness score was $38.44 \pm 9.43$ points. This resulted in 21 subjects $(10.5 \%)$ being assigned to the "not particularly lonely group," 120 $(60.0 \%)$ to the "moderately lonely group," and 59 (29.5\%) to the "severely lonely group" (Table 2 ).

\section{(2) Determining loneliness using the UCLA}

\section{Loneliness Scale, LSNS-6, and MSPSS}

In this analysis, only 199 respondents who completed all of the questions in the interview schedule were included.

There were $45(22.6 \%)$ respondents in the "lonely group" and 154 (77.4\%) in the "not lonely group." The mean \pm standard deviation scores on the UCLA Loneliness Scale were $50.76 \pm 5.26$ for the "lonely group" and $34.68 \pm 6.68$ for the "not lonely group" (Table 3).

\section{(3) Loneliness and its associated factors}

After performing $\chi^{2}$ tests on the "lonely group" and the "not lonely group" and each of the associated factors, we found that a significant number of individuals in the "lonely group" were not socially active $(p=0.010)$, lived in an apartment complex $(p=0.036)$, or did not have any hobbies $(p=0.037)$. Furthermore, there was a trend for lonely respondents to have numerous subjective symptoms $(p=0.053)$, heart disease $(p=0.081)$, or bereavement experience $(p=0.075)$ (Table 4$)$.

The results of the multiple logistic regression analyses, which used the items that were significant on the $\chi^{2}$ test as the independent variables and loneliness as the dependent variable, revealed that social participation [odds ratio (OR): 0.148 ; $95 \%$ confidence interval $(\mathrm{CI}): 0.03-0.66 ; p=0.012]$ and type of residence (OR: $0.464 ; 95 \% \mathrm{CI}: 0.23$ $0.94 ; p=0.033)$ were significantly associated with loneliness (Table 5).

\section{Discussion}

\section{Extent of loneliness}

The mean \pm standard deviation score for the respondents on the UCLA Loneliness Scale was 38.44 \pm 9.43 . In previous research, the solitude scale scores for elderly men who experienced death of a spouse $^{14)}$, elderly people residing in rural areas ${ }^{16)}$, middle-to-old-aged people attending senior colleges ${ }^{32)}$, latter-stage elderly undergoing arteriosclerosis screening ${ }^{19)}$, and elderly people living at home in the community with their spouses ${ }^{33)}$ were reported as $42.4 \pm 7.56,49.05 \pm 4.77,38.47 \pm$ 
Table 1 Demographic characteristics of the older people

\begin{tabular}{|c|c|c|c|c|c|c|c|c|c|}
\hline factors & \multicolumn{3}{|c|}{ Characteristics } & \multicolumn{2}{|c|}{$\mathrm{n}(\%)$} & \multicolumn{2}{|c|}{ Characteristics } & & $\mathrm{n}(\%)$ \\
\hline \multirow{30}{*}{ 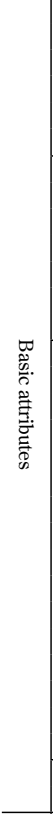 } & \multirow{3}{*}{ Gender } & \multirow{2}{*}{\multicolumn{2}{|c|}{$\begin{array}{l}\text { Male } \\
\text { Female }\end{array}$}} & \multirow{2}{*}{$\begin{array}{r}53 \\
147\end{array}$} & \multirow{2}{*}{$\begin{array}{l}(26.5) \\
(73.5) \\
\end{array}$} & & & & \\
\hline & & & & & & & & & \\
\hline & & & $65-74$ & 19 & (9.5) & & & & \\
\hline & Age group & & $75-84$ & 81 & $(40.5)$ & & & & \\
\hline & (years) & & $85-94$ & 90 & $(45.0)$ & & & & \\
\hline & & & $\geqq 95$ & 10 & $(5.0)$ & & & & \\
\hline & & & $<1$ & 68 & $(34.0)$ & & Once a week & 58 & $(29.0)$ \\
\hline & & & $1-2$ & 40 & $(20.0)$ & & Twice a week & 73 & $(36.5)$ \\
\hline & Use of day care & & $2-3$ & 30 & $(15.0)$ & & Three times a week & 32 & $(16.0)$ \\
\hline & services & $\begin{array}{l}\text { Duration of use } \\
\text { (vears) }\end{array}$ & $3^{-4}$ & 22 & $(11.0)$ & frequency of use & Four a times a week & 20 & $(10.0)$ \\
\hline & & & $4-5$ & 8 & $(4.0)$ & & Others & 17 & (8.5) \\
\hline & & & $\geqq 5$ & 24 & $(12.0)$ & & & & \\
\hline & & & unknown & 8 & $(4.0)$ & & & & \\
\hline & & & One-person household & 78 & $(39.0)$ & & One-person household & 78 & $(39.0)$ \\
\hline & & & Household of couple & 32 & $(16.0)$ & & Living together & 122 & $(61.0)$ \\
\hline & & Family situation & Nuclear family household & 45 & $(22.5)$ & & & & \\
\hline & & ramily situation & $\begin{array}{l}\text { Three-generation-family } \\
\text { household }\end{array}$ & 37 & (18.5) & & & & \\
\hline & & & Other-households & 8 & $(4.0)$ & & & & \\
\hline & & Marital status & Married & 182 & $(91.0)$ & Current spouse & Yes & 57 & $(28.5)$ \\
\hline & Family situation & vartar status & Single & 18 & $(9.0)$ & Curremt spouse & No & 143 & $(71.5)$ \\
\hline & Family situation & & Yes & 171 & (85.5) & & & & \\
\hline & & Children & No & 28 & $(14.0)$ & & & & \\
\hline & & & Unknown & 1 & $(0.5)$ & & & & \\
\hline & & Experienced & Yes & 121 & $(60.5)$ & & $0-1$ & 7 & $(5.8)$ \\
\hline & & bereavement & No & 79 & $(39.5)$ & Duration of & $1-5$ & 21 & (17.4) \\
\hline & & & & & & bereavement & $5-10$ & 15 & (12.4) \\
\hline & & & & & & (years) & $\geqq 10$ & 75 & $(62.0)$ \\
\hline & & & & & & & Unknown & 3 & $(2.5)$ \\
\hline & Hobhies & & Yes & 111 & (55.5) & & & & \\
\hline & HoDDIes & & No & 89 & $(44.5)$ & & & & \\
\hline & & & Requiring help & 51 & $(25.5)$ & & & & \\
\hline $\overrightarrow{0}$ & Long-term care lever & & Long-term care level & 125 & $(62.5)$ & & & & \\
\hline s. & & & Brain disease & 55 & $(27.5)$ & & Mental disease & 15 & (7.5) \\
\hline 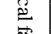 & & & Heart disease & 47 & (23.5) & & Cancer & 23 & (11.5) \\
\hline  & Illness & & High blood pressure & 72 & $(36.0)$ & & Articular diseases & 27 & (13.5) \\
\hline$\stackrel{8}{a}$ & & & Arrhythmia & 48 & $(24.0)$ & & Others & 125 & $(62.5)$ \\
\hline & & & Diabetes & 25 & (12.5) & & & & \\
\hline & & & 0 & 9 & $(4.5)$ & & Depression & 82 & $(41.0)$ \\
\hline 逍 & $\begin{array}{l}\text { Subjective } \\
\text { percentions of }\end{array}$ & Number of & $1-5$ & 58 & $(29.0)$ & & Irritability & 52 & $(26.0)$ \\
\hline$\frac{0}{\circ}$ & healthiness & symptoms & $6-10$ & 100 & $(50.0)$ & & & & \\
\hline & & & $\geqq 11$ & 33 & $(16.5)$ & & & & \\
\hline & & & Low $(<12)$ & 119 & (59.5) & & Low $(12-48)$ & 96 & $(48.0)$ \\
\hline & Social network & & High $(\geqq 12)$ & 81 & $(40.5)$ & & Middle (49-68) & 90 & $(45.0)$ \\
\hline & & & & & & Social support & High (69-84) & 13 & (6.5) \\
\hline & & & & & & & Unknown & 1 & $(0.5)$ \\
\hline & Outings & Outings to & Stay indoors & 76 & $(38.0)$ & & Stay indoors & 76 & $(38.0)$ \\
\hline 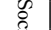 & & destinations & 1-2 times a week & 37 & (18.5) & & Go out & 124 & $(62.0)$ \\
\hline ڤ. & & other than day & $2-3$ times a week & 26 & (13.0) & & & & \\
\hline ڤ્ & & care service & Everyday & 61 & $(30.5)$ & & & & \\
\hline$\vec{s}$ & & Social & Yes & 34 & (17.0) & & & & \\
\hline & & participation & No & 166 & $(83.0)$ & & & & \\
\hline & & Home-visit & Yes & 81 & $(40.5)$ & Day-rehabilitation & Yes & 32 & $(16.0)$ \\
\hline & Use of services & service & No & 119 & (59.5) & service & No & 168 & $(84.0)$ \\
\hline & communication & Mohile nhone & Yes & 66 & $(33.0)$ & Internet & Yes & 9 & $(4.5)$ \\
\hline & communication & Mobile phone & No & 134 & $(67.0)$ & Internet & No & 191 & $(95.5)$ \\
\hline & & & A & 70 & $(35.0)$ & & Urban & 135 & (67.5) \\
\hline & & & $\mathrm{B}$ & 4 & $(2.0)$ & & Rural & 65 & (32.5) \\
\hline & & & $\mathrm{C}$ & 14 & $(7.0)$ & & & & \\
\hline & & location of & $\mathrm{D}$ & 17 & (8.5) & & & & \\
\hline 宓 & & residence & $\mathrm{E}$ & 30 & $(15.0)$ & & & & \\
\hline$\leqq$ & & & $\mathrm{F}$ & 26 & (13.0) & & & & \\
\hline 兽 & & & $\mathrm{G}$ & 39 & (19.5) & & & & \\
\hline 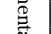 & Residence & Type of & Detached house & 133 & $(66.5)$ & & $<5$ & 28 & $(14.0)$ \\
\hline $\overrightarrow{\overrightarrow{ \pm}}$ & & residence & Apartment house & 67 & (33.5) & & $5-10$ & 17 & (8.5) \\
\hline $\overrightarrow{\vec{a}}$ & & & & & & Duration of stay in & $10-20$ & 20 & $(10.0)$ \\
\hline$\stackrel{S}{a}$ & & & & & & their current & $20-30$ & 8 & (4.0) \\
\hline & & & & & & residence & $30-40$ & 27 & (13.5) \\
\hline & & & & & & (years) & $40-50$ & 13 & (6.5) \\
\hline & & & & & & & $\geqq 50$ & 86 & $(43.0)$ \\
\hline & & & & & & & Unknown & 1 & $(0.5)$ \\
\hline
\end{tabular}


Table 2 Classification of Loneliness Using the UCLA Loneliness Scale (Version 3)

\begin{tabular}{lcccc}
\multicolumn{1}{c}{ Classification of Loneliness } & $\mathrm{n}$ & (\%) & $\min$ & $\max$ \\
\hline Have low loneliness point (between 20-27) & 21 & 10.5 & 22 & 27 \\
Have middle loneliness point (between 28-43) & 120 & 60.0 & 28 & 43 \\
Have high loneliness point (between 44-80) & 59 & 29.5 & 44 & 64 \\
\hline
\end{tabular}

Table 3 Determining loneliness using the UCLA Loneliness Scale, LSNS-6, and MSPSS

\begin{tabular}{|c|c|c|c|c|c|c|}
\hline & & & & & & $\mathrm{N}=$ \\
\hline \multirow{2}{*}{$\begin{array}{l}\text { Classification of } \\
\text { Loneliness }\end{array}$} & \multirow{2}{*}{$\mathrm{n}$} & \multirow{2}{*}{$(\%)$} & \multicolumn{4}{|c|}{ Loneliness scores } \\
\hline & & & $\min$ & $\max$ & Mean & $\pm \mathrm{SD}$ \\
\hline Lonely & 45 & 22.6 & 44 & 62 & 50.76 & \pm 5.26 \\
\hline Not lonely & 154 & 77.4 & 22 & 54 & 34.68 & \pm 6.68 \\
\hline
\end{tabular}

Table 4 Loneliness and its associated factors

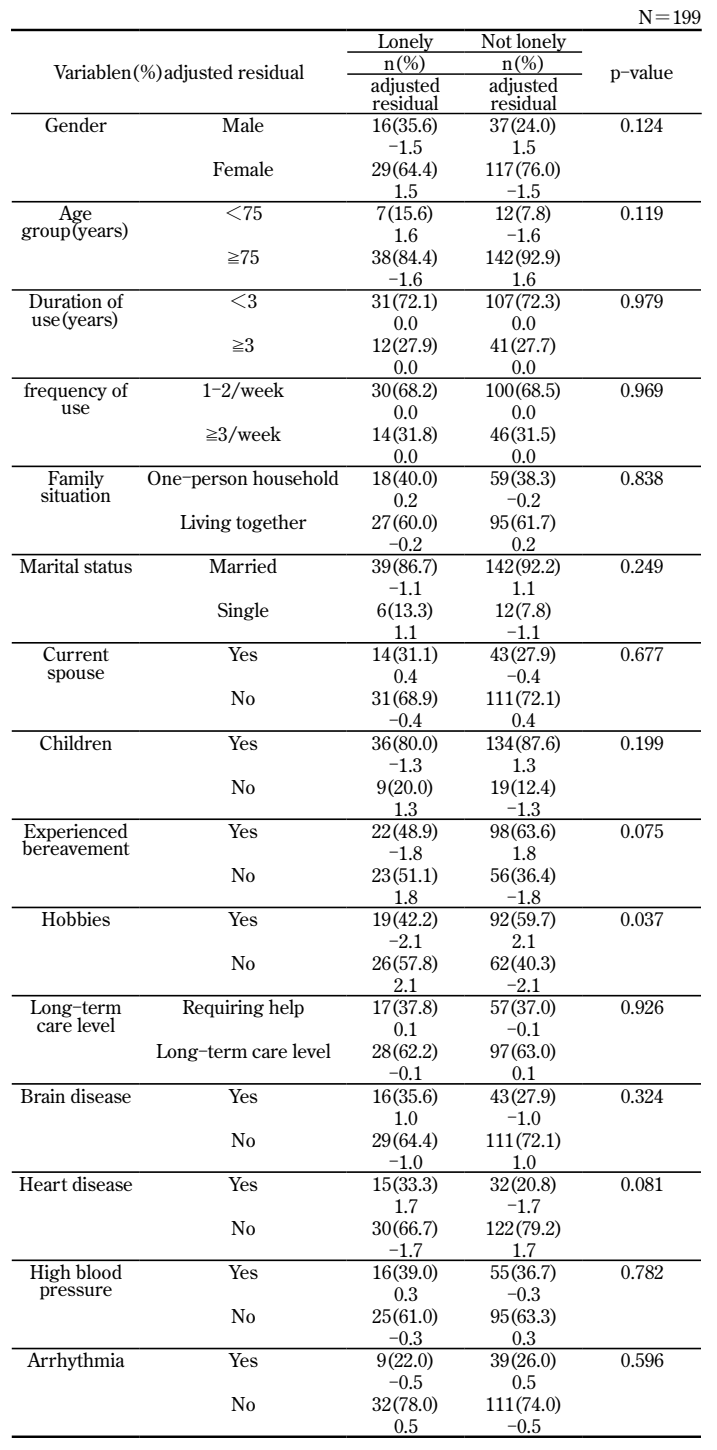

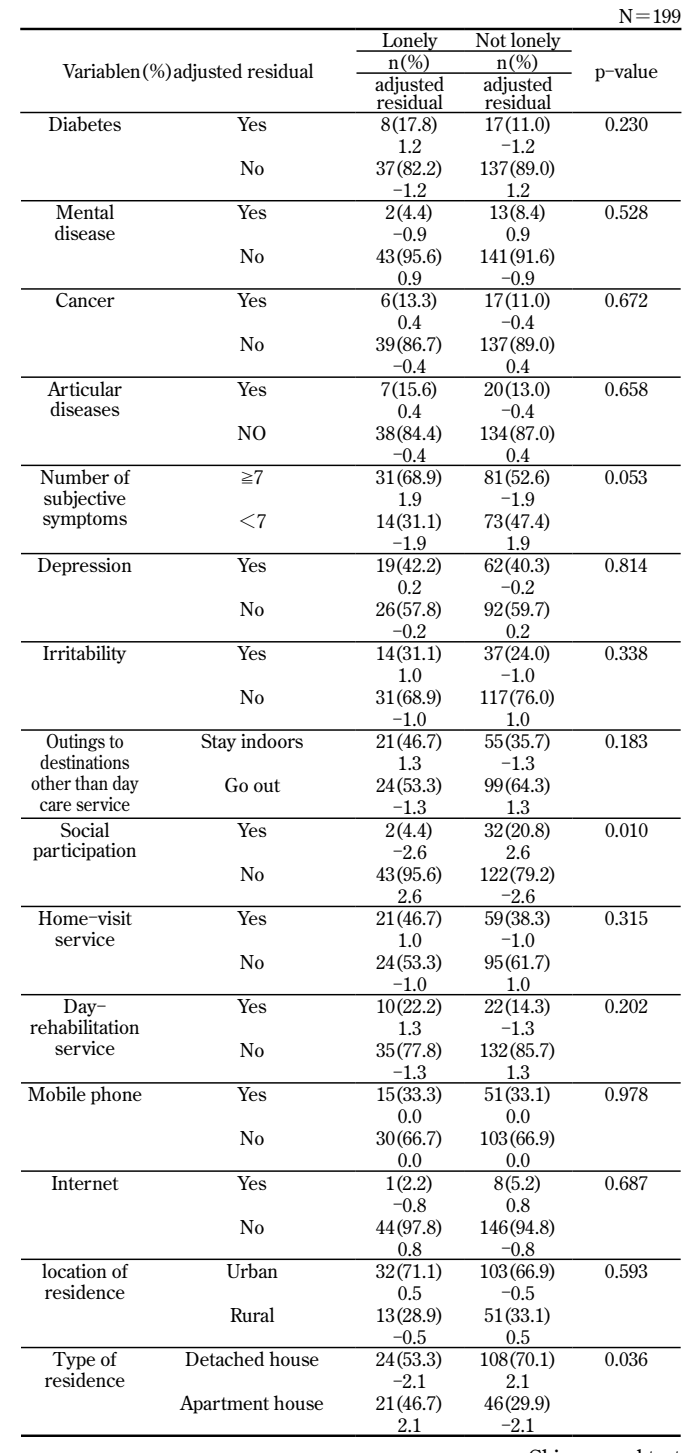


Table 5 Factors associated with loneliness

\begin{tabular}{|c|c|c|c|c|c|}
\hline & & Odds Ratio & $95 \% \mathrm{Cl}$ & $\mathrm{p}^{-}$value & Hosmer-Lemeshow test \\
\hline \multirow{2}{*}{ Type of residence } & Detached house & Reference & ( 22- 040 & 0022 & \multirow{4}{*}{$\mathrm{p}=0.892$} \\
\hline & Apartment house & 0.464 & 0.250 .74 & 0.050 & \\
\hline \multirow{2}{*}{ Social participation } & Yes & Reference & \multirow{2}{*}{$0.03-0.66$} & \multirow{2}{*}{0.012} & \\
\hline & No & 0.148 & & & \\
\hline
\end{tabular}

Logistic regression analysis (backward elimination method)

9.67, $36.5 \pm 7.6$, and $37.1 \pm 8.5$, respectively. Therefore, it is apparent that the solitude scale score tended to be low in our study.

Lower frequency of interacting with friends and acquaintances has been shown to be associated with higher feelings of solitude ${ }^{33)}$. However, there are elderly people with strong feelings of solitude even among users of visiting day care facilities; therefore, it is necessary to consider the associated relevant factors in order to devise methods of alleviating feelings of solitude.

\section{Factors associated with loneliness}

Many elderly people in the "lonely group" were not socially active, did not have hobbies, or lived in apartment complexes. The results of multiple logistic regression analyses revealed that social participation and type of residence were significantly associated with loneliness.

Chalise $^{13)}$ demonstrated that elderly people who were socially active and who had a large social network were less lonely, which is similar to the results of this study. It has been reported that elderly people who require care are more likely to be socially isolated ${ }^{2,3)}$. In this study, more than $80 \%$ of respondents were not socially active and had small social networks; therefore, many were lonely. Previous research has also indicated that elderly individuals living in apartment complexes experience greater social isolation and those remaining confined at home always experience a high level of loneliness $^{34-36)}$. One of the main purposes of day care services is to alleviate isolation ${ }^{17)}$; however, day care service users rarely go out and many live in apartment complexes. It is, therefore, likely that many of them experience feelings of loneliness. Furukawa et al. ${ }^{37)}$ also demonstrated an association between loneliness and hobbies consistent with the findings of this study. Elderly people who are socially active often maintain a hobby and through their hobbies, they maintain opportunities to interact socially. Moreover, spending time immersed in hobbies reduces their sense of loneliness.

Therefore, this study showed that loneliness in the elderly is clearly associated with their social participation and living situations, as well as hobbies and activities. These findings have important implications for understanding loneliness in community-living elderly people who use day care services.

\section{Limitations}

The limitations of this study are that the subjects were selected by convenience sampling and therefore, sample representation may be biased by geographic region or number of subjects. In addition, because analysis was not conducted according to facility characteristics, ways by which facility characteristics influence feelings of solitude need to be investigated. Furthermore, the initial selection of the subjects was made by the day care service providers who introduced the elderly people in their facilities, and the respondents were ultimately self-selected on the basis of their willingness to cooperate in the study. Therefore, it was unclear whether we were able to reach those elderly people 
who were severely lonely but could not express it. Further studies are required using a larger sample size and a more detailed survey.

\section{Conclusion}

The results of this study demonstrated that elderly people who use day care services, even among those living in a community, tend to be very lonely. The factors associated with loneliness were found to be social activity and type of residence. This provided validation that lonely elderly people tend to be socially inactive and live in apartment complexes.

\section{Acknowledgments}

We would like to offer our sincere thanks to the respondents for participating in this study.

\section{References}

1) Elderly person white paper. Cabinet Office, Government of Japan.

http://www8.cao.go.jp/kourei/whitepaper/ w-2015/zenbun/27pdf_index.html (cited February 1, 2016).

2) Saito M, Fujiwara Y, Kobayashi E, et al. Prevalence and characteristics of social isolation in the elderly in a dormitory suburb according to household composition. Jpn J Public Health, 2010; 57 (9): 785795 (in Japanese).

3) Saito M, Shimizu Y, Yamaguchi M, et al. Prevalence and characteristics of the socially isolated elderly in a large urban area. Jpn J Social Welfare, 2009; 50(1): 110-122 (in Japanese).

4) Hoshina Y, Okuno E. A Functional analysis of the volunteer as a partner: conversation and communication for senior citizens living at home. Jpn J Social Welfare, 2008; 49(2): 111-121 (in Japanese).

5) Tadaka E, Kono A, Kunii Y, et al. Development and evaluation of the effects of a community based program to promote self care and neighborhood cohesion on elderly men living alone in an urban city. J Jpn Acad Com Health Nurs, 2012; 14(2): 53-61(in Japanese).

6) Townsend P, Shanas E, Wedderburn D, et al. Older people in three industrial societies, New York: Ath- erton, 1968: 478.

7) Ochiai Y. A hypothesis on the intensional structure of loneliness. J Clin Edu Psychol, 1982; 30(3): 233238(in Japanese).

8) Momtaz YA, Hamid TA, Yusoff S, et al. Loneliness as a risk factor for hypertension in later life. J Aging Health, 2012; 24(4): 696-710.

9) Drageset J, Eide GE, Kirkevold M, et al. Emotional loneliness is associated with mortality among mentally intact nursing home residents with and without cancer: a five-year follow-up study. J Clin Nurs, 2013; 22(1-2): 106-114.

10) Perissinotto CM, Stijacic Cenzer I, Covinsky KE. Loneliness in older persons: a predictor of functional decline and death. Arch Intern Med, 2012; 172(14): 1078-83.

11) Wilson RS, Krueger KR, Arnold SE, et al. Loneliness and risk of Alzheimerdisease. J Cross Cult Gerontol, 2012; 27(1): 65-78.

12) Katsura T, Hoshino A, Watabe Y. Factors reducing loneliness of old people living alone. J Jpn Assoc Rural Med, 1988; 47(1): 11-15(in Japanese).

13) Chalise HN, Saito T, Kai I. Correlates of loneliness among older Newar adults in Nepal. Jpn J Public Health, 2007; 54(7): 427-433.

14) Suzuki H, Takigawa S. Loneliness and related factors of men with the bereavement experience with partner. Hosp Home Care, 2005; 13(3): 238-243(in Japanese).

15) Akin S, Mendi B, Ozturk B, et al. Assessment of relationship between self- ${ }^{-}$are and fatigue and loneliness in haemodialysis patients. J Clin Nurs, 2014; 23: 856-864.

16) Theeke LA, Mallow J. Loneliness and quality of life in chronically ill rural older adults, Am J Nurs, 2013; 113(9): 28-37.

17) Ministry of Health, Labour and Welfare. http:// www.kaigokensaku.jp/(cited February 1, 2016)

18) Makino M, Tanaka T, Matsuda M, et al. Study on related factors inducing loneliness to the patient in a single room of the hospital. J Comprehensive Nurs Res, 2007; 10(1): 15-29(in Japanese).

19) Ishitani $T$, Hattori $S$, Suishu $C$. The status of subjective health, loneliness and social interaction and the factors related to subjective health among the elderly aged75 or over who underwent a medical checkup to prevent against arterial sclerosis. J Jpn Acad Gerontol Nurs, 2014; 19(1): 72-80(in Japanese).

20) Kvaal K, Halding AG, Kvigne K. Social provision and loneliness among older people suffering from 
chronic physical illness, A mixed-methods approach. Scand J Caring Sci, 2014; 28 (1): 104-111.

21) Zeliha K. Determination of older people's level of loneliness. J Clin Nurs, 2012; 21: 3037-3046.

22) Peplau LA, Perlman D. Perspective on loneliness: A sourcebook of current theory, research, andtherapy, Jhon Wiley\&Sons, 1982; 1-18.

23) Hirosawa T. A Psychological study of loneliness: Tasks and perspectives. Kansai University of Int Studies, 2011; 12: 145-152(in Japanese).

24) Kato S, Hasegawa K, Shimogaki H, et al. Development of the revised version of Hasegawa's dementia scale (HDS-R), Jpn J Geriatric Psychiatry, 1991; 2: 1339-1347.

25) Welfare And Medical Service Agency, WAMNET. http://www.wam.go.jp/content/wamnet/pcpub/ top/ (cited February 1, 2016).

26) Russell DW. UCLA Loneliness Scale (Version 3): reliability, validity, and factor structure, J Pers Assess, 1966; 66(1): 20-40.

27) Masuda Y, Tadaka E, Dai Y. Reliability and Validity of the Japanese Version of the UCLA Loneliness Scale Version 3 among the Older Population. J Jpn Acad Com Health Nurs, 2012; 15(1): 25-32(in Japanese).

28) Lubben J, Blozik E, Gillmann G, et al. Performance of an abbreviated version of the Lubben Social Network Scale among three European community-dwelling older adult populations. Gerontologist, 2006; 46(4): 503-513.

29) Kurimoto A, Awata S, Ookubo T, et al. Reliability and validity of the Japanese version of theabbreviated Lubben Social Network Scale. Jpn J Geriatrics, 2011; 48(2): 149-157.
30) Zimet GD, Dahlem NW, Walker RR, et al. The Multidimensional Scale of Perceived Social Support. J Pers Asses, 1988; 52(1): 30-41.

31) Iwasa H, Gondo Y, Masui Y, et al. Reliability and validity of the Japanese version Multidimensional Scale of Perceived Social Support. J Health Welfare Statistics, 2007; 54(6): 26-33(in Japanese).

32) Toyoshima A, Sato S. Relationship between social support and mental health mediated by loneliness among the middle-aged and elderly: An investigation using the UCLA Loneliness Scale Version 3. Jpn J Gerontol, 2013; 35(1): 29-38(in Japanese).

33) Yonezawa H, Ishizu M, Kai I. Loneliness of elderly and relationships with family members and friends: An analysis by family composition, Health Sciences, 2002; 18(3): 194-206(in Japanese).

34) Kei Fengmei, Sato $W$. The characteristics and related factors of housebound in elderly stroke patients in a city Northeast of China, J Jpn Acad Gerontol Nurs, 2008; 13(1): 32-39(in Japanese).

35) Gouda K, Okamoto R. Current status of and factors associated with social isolation in the elderly living in a rapidly aging housing estate community, Environ Health Prev Med, 2012; 17 (6): 500-511.

36) Arai K, Sakakibara H. Malnutrition and social isolation among elderly residents of city public housing, Jpn J Public Health, 2015; 62(8): 379-389.

37) Furukawa H, Kokubu K, Noguchi F. Loneliness and depression among elderly people and effectsof participation in social activities-Results of a survey based on elderly Japanese Americans living in Hawaii, U.S.A.- . Jpn J Gerontol, 2004; 26(1): 85-91(in Japanese).

(Received 3.2.2016 ; Accepted 3.29.2017) 


\title{
Loneliness and its associated Factors in Community-living Elderly People who Use Day Care Services
}

\author{
Akira NARUSAWA, Yumiko SAKATA and Yuriko TAKATA
}

Jpn J Health \& Human Ecology, 83(5)139-148 2017

\section{和文抄録}

本研究は，通所介護サービスを利用している高龄者を対象に，孤独感の実態と孤独感に関連す る要因を明らかにすることを目的とした。通所介護サービスを利用している高龄者に対して，質 問紙を用いた聞き取り調査を実施した。孤独感と各要因の独立性を検討するために $\chi^{2}$ 検定を行 い，有意性の確認された項目を独立変数，孤独感の有無を従属変数とする多重ロジスティック回 帰分析を行った。

調査対象者は，通所介護サービスを利用している地域在住高齢者 200 名であり，男性 53 名 (26.5\%)，女性 147 名（73.5\%）であった。孤独感尺度得点の平均は $38.44 \pm 9.43$ 点であった。 $\chi^{2}$ 検定の結果, 「孤独感あり群」では, 社会参加していない $(\mathrm{p}=0.010)$, 集合住宅に住んでいる $(\mathrm{p}=0.036)$, 趣味がない $(\mathrm{p}=0.037)$ 高歯者が有意に多かった。また，多重ロジステイック回帰分 析の結果, 社会参加 (オッズ比 $0.148,95 \% \mathrm{CI} ; 0.03-0.66, \mathrm{p}=0.012$ ), 住宅形態（オッズ比 0.464, 95\% CI;0.23-0.94, $\mathrm{p}=0.033 ）$ が孤独感に有意な関連があった.

以上のことから, 社会参加や趣味の有無, 住宅形態が高齢者の孤独感に関連することが明らかになり, 通所介護サービスを利用している地域在住高齢者の孤独感を把握する上で重要である. 